\title{
DZIEWIĄTE ZGROMADZENIE ŚWIATOWEJ RADY KOŚCIOŁÓW W PORTO ALLEGRE, LUTY 2006
}

Po raz pierwszy od powstania ŚRK w 1948 roku jej zgromadzenie odbyło się w Ameryce Południowej. Dziewiąte Zgromadzenie miało miejsce w brazylijskim Porto Allegre w dniach od 14 do 23 lutego 2006 roku. Wzięły w nim udział ponad 4 tysiące osób, w tym 691 delegatów z 348 Kościołów członkowskich oraz obserwatorzy i reprezentanci z innych Kościołów, organizacji i ruchów.

Podczas zamknięcia Zgromadzenia sekretarz generalny ŚRK ks. Dr Samuel Kobia stwierdził, że „potwierdziło ono żywotność ruchu ekumenicznego oraz zaangażowanie Kościołów na rzecz wizji ekumenicznej i jedności, a także ich starania o bardziej sprawiedliwy i pokojowy świat". W czasie obrad podnoszono m.in. kwestię współpracy z Kościołem katolickim niebędącym członkiem ŚRK oraz Kościołami zielonoświątkowymi.

Uczestniczący w Zgromadzeniu kardynał Walter Kasper, przewodniczący Papieskiej Rady ds. Popierania Jedności Chrześcijan, stwierdził w jednym z wywiadów, że Kościół rzymskokatolicki pozostaje poza Światową Radą Kościołów z przyczyn strukturalnych, stanowi bowiem ciało o zasięgu globalnym, analogiczne do ŚRK, z którą współdziała nie w oparciu o „rywalizację lub współzawodnictwo, lecz o życzliwą współpracę". Współdziałanie Rady i Kościoła

* Mgr Marcin Ziemkowski jest asystentem w Zakładzie Polityki Społecznej Instytutu Socjologii UMK. 
rzymskokatolickiego, prowadzącego obecnie szesnaście ekumenicznych dialogów dwustronnych, może przynieść ważkie efekty dla światowej ekumenii, na którą oddziaływuje dziś m.in. rozwój ruchu zielonoświątkowego, zaznaczył kardynał Kasper. Rozwijające się Kościoły ewangelikalne i zielonoświątkowe stanowią wyzwanie dla katolicyzmu co do efektywności jego duszpasterstwa i jakości kultu. Dialog z nimi utrudnia to, że nie są one zorganizowane w większe całości (jak np. Światowa Federacja Luterańska lub Światowy Alians Kościołów Reformowanych). Przekłada się to na brak jednolitej teologii, co czyni dialog wręcz niemożliwym, zwłaszcza że ruch neozielonoświątkowy wciąż ewoluuje i nie wiadomo, czym zakończy się jego rozwój.

Inną przyczyną ekumenicznych problemów jest stanowisko Kościołów wobec homoseksualizmu. Jak zauważył watykański hierarcha, w przeszłości chrześcijaństwo mówiło na ten temat jednym głosem. Obecnie temat ten jest przyczyną podziałów zarówno pomiędzy Kościołami, jak i wewnątrz nich. Dotyczy to pewnych problemów antropologicznych, domagających się przedyskutowania i rozwiązania. Kościół katolicki, podkreślił kardynał, sprzeciwia się wszelkim formom dyskryminacji, co - jak można domniemywać - dotyczy w tej samej mierze osób homoseksualnych, jak i heteroseksualnych.

Ważnym owocem Dziewiątego Zgromadzenia Światowej Rady Kościołów jest dokument "Wezwani do bycia jednym Kościołem” (Called to be the one chuch). Stanowi on zaproszenie do kontynuowania przez chrześcijan starań na rzecz jedności. Zaproszenie to ma ułatwić Kościołom ustalenie, na ile mogą mówić jednym głosem na ważne tematy eklezjologiczne, oraz zachęcić je do otwartego i szczerego dialogu dotyczącego istniejącej między nimi komunii, a także spraw, które wciąż dzielą chrześcijan.

Kościoły tworzące ŚRK podtrzymują swoje zaangażowanie na rzecz osiągnięcia pełnej, widzialnej jedności, będącej zarazem darem Boga, jak i pochodzącym od Niego wezwaniem. Modelem jedności jest koinonia, przejawiająca się we wspólnym wyznawaniu wiary apostolskiej i życiu sakramentalnym, inicjowanym przez chrzest, kultywowanym poprzez zgromadzenie eucharystyczne. Znakiem koinonii jest również wzajemne uznawanie posługiwania duchownego, wspólne zaangażowanie w głoszeniu Ewangelii i służbie na rzecz stworzenia. Koinonia winna istnieć poprzez soborowe/synodalne (conciliar) relacje między Kościołami na całym świecie. Wyzwaniem dla chrześcijan pozostaje wspólne ustalenie sensu jedności i powszechności Kościoła oraz doniosłości chrztu.

Kościół, będący Ludem Bożym, Ciałem Chrystusa oraz Świątynią Ducha Świetego, jest powołany do stanowienia jedności w bogatej różnorodności (onennes in rich diversity). Apostolska wiara Kościoła, jakkolwiek jedna, może być wyrażana na różne sposoby. Jednością jest również nowe życie Kościoła w Chrystusie, niemniej składają się na nie różne posługiwania i charyzmaty. Kościół żywi jedną nadzieję, która przejawia się jednak w różnych ludzkich 
oczekiwaniach. Niektóre spośród różnic są wyrazem bożej łaski i dobroci, inne zaś osłabiają Kościół i muszą być przezwyciężone w imię dążenia do pełni koinonii. Sprawą otwarta pozostaje jednak pytanie, co mieści się w granicach bogatej różnorodności, a co wykracza poza nią, oznaczając pogłębienie podziałów?

Powszechność (catholicity) Kościoła znajduje wyraz w każdej wspólnocie ochrzczonych wyznających wiarę apostolską, w której sprawowane są sakramenty i głoszona jest Ewangelia. Każdy Kościół zasługuje na miano powszechnego, lecz nie stanowi jego całości. Powszechność Kościoła wyraża się najpełniej we wspólnym celebrowaniu komunii świętej i wzajemnym uznawaniu posługiwań duchownych.

Relacje pomiędzy Kościołami mają charakter dynamiczny. Każdy z nich jest wezwany do udzielania i przyjmowania darów oraz przyjmowania postawy współodpowiedzialności. Postawa ta przejawia się m.in. w dzieleniu się zasobami, współpracy w dziełach miłosierdzia, wspólnym podejmowaniu decyzji oraz podtrzymywaniu dialogu, pomimo istniejących różnic.

Chrzest, poprzez który członkom Kościoła udzielana jest świętość Chrystusa, jest wezwaniem Kościołów do otwartości i uczciwości we wzajemnych relacjach. Chrzest obdarza Kościoły wolnością, a zarazem odpowiedzialnością za wspólne podążanie ku jedności. Niektóre spośród Kościołów nie kultywują rytu chrztu poprzez wodę, lecz wyrażają wspólną chrześcijanom wolę bycia wiernym Chrystusowi. Poprzez chrzest uwidacznia się prawda mówiąca, że przynależymy do siebie nawzajem, pomimo że niektóre spośród Kościołów nie postrzegają jeszcze innych jako Kościoły w pełnym znaczeniu. Przynależność do Kościoła Chrystusa jest bardziej wszechogarniająca niż uczestnictwo w partykularnym Kościele.

Łaska boża wyraża się w zwycięstwie Chrystusa nad grzechem i w uzdrowieniu człowieka. Królestwo boże trwa w pojednanej i jednającej się wspólnocie, wezwanej do świętości. Wspólnota ta winna dążyć do zniesienia dyskryminacji wynikającej z istnienia grzesznych struktur społecznych oraz przezwyciężenia podziałów swym łonie, a także w całej ludzkości.

Światowa Rada Kościołów stanowi wyjątkowe forum ekumeniczne. Niemniej tworzące ją Kościoły nie zawsze przejawiały świadomość bycia współodpowiedzialnymi za siebie nawzajem. Obecna sytuacja domaga się podjęcia konkretnych działań, które miałyby to zmienić. Dziewiąte Zgromadzenie wzywa Kościoły członkowskie ŚRK do oceny ich wzajemnych relacji dotyczących wiary i ustroju kościelnego. Postęp ekumeniczny wymaga uczciwego oszacowania rzeczy wspólnych, rozbieżności, a także różnic w życiu Kościołów chrześcijańskich. Refleksja ta winna dotyczyć m.in. następujących kwestii: na ile Kościoły postrzegają życie, modlitwę i świadectwo własne i innych jako wierną realizację wiary apostolskiej; czy panuje pomiędzy nimi zgodność co do uznawania chrześcijańskiej inicjacji, wyrastającej z chrztu, w życiu innych; dlaczego niektóre 
spośród Kościołów uważają współudział w Wieczerzy Pańskiej za niezbędny, inne za dozwolony, jeszcze inne zaś za niedozwolony; w jaki sposób Kościoły mogą uznawać posługę duchownych spoza nich samych; do jakiego stopnia Kościoły mogą czerpać z duchowości innych; na ile możliwe jest uczestnictwo we wspólnej modlitwie i w życiu kultowym innych Kościołów.

Powyższe pytania mogą stanowić przyczynek do odnowy własnego życia Kościołów i pogłębienia relacji z innymi. W zakończeniu dokumentu można przeczytać, że Kościoły tworzące ŚRK mają świadomość wspólnego podążania ku jedności, której coraz głębsze znaczenie objawia zmartwychwstały Chrystus. 